\title{
MEMOIR
}

\section{NORMAN BENZ}

Norman Bfnz was born on 15 June 1913. He was educated at St Paul's School and Christ's College, Cambridge, where he took a first-class degree in mathematics. He then jointed Equity \& Law where he spent the whole of his career. After less than 4 years, he was appointed Acting Assistant Actuary in 1940, 2 years before he qualified as a Fellow of the Institute. After a succession of actuarial appointments, he became Deputy Manager and Actuary in 1954 and General Manager and Actuary in 1966. He retired in 1974, but remained on the Board for a further 10 years to complete more than 47 years' service to the office.

He was on Council for 3 terms between 1951 and 1971, Chairman of the Board of Examiners from 1953 to 1955, Honorary Secrelary from 1958 to 1960 and Vice-President from 1961 to 1964. He was joint author with H. J. Tappenden of the examination textbook Valuation of Reversions and Life Interests, and presented 2 papers to the Institute, both admirably brief,-- Valuation of Reversions and Life Interests for the Purposes of Apportionment of Trust Funds' in 1953 and 'Some Notes on Bonus Distributions by Life Offices' in 1959.

He also did much work for the Life Offices' Association, where he was Chairman of the Taxation Committec and a member of the Management Committec, and he took a keen interest in the Chartered Insurance Institute, becoming a Vice-President.

At Equity \& Law he was responsible in the post-war years for the recruitment of actuarial trainees, many of whom became prominent in the profession, including two Finlaison medallists and 9 members of Council. Later he supervised the transfer of part of the head office to High Wycombe and the subsequent construction and successive extension of purpose-built offices there. When he became General Manager, he instituted a drive for new business in the United Kingdom, and made many visits to Common Market countries which led to the establishment of successful branch operations in Holland and Germany.

After marrying Elizabcth in 1948, Norman returned to live in his home town, Eastbourne, and he read voraciously on the train journeys to and from work. He collected pictures, topographical drawing and books, and his many interests and very retentive memory made him knowledgeable on a surprisingly large range of topics.

Despite being a large man, he was very vigorous physically as well as mentally. Hc had considerablc force of personality and his quickness of mind sometimes resulted in impatience, but behind the sometimes brusque manner lay an interest in, and sympathy with, others, and he made a point of getting to know members of the staff throughout the organisation at home and abroad. He greatly enjoyed convivial company and was a genial host.

In retirement he did much for the Conservative Association in Fastbourne where the MP was lan Gow, the son of the former Principal Medical Oflicer of Equity \& Law. Elizabeth died in 1984, and soon after Norman's health began to decline, making it progressively more difficult for him to get about. He died in a nursing home on 17 December 1992.

M. J. BURNS 